\title{
Mineralogy and genesis of soils developed from ultrabasic and alkaline rocks of Lages Alkaline Complex, Brazil
}

\author{
Ágata Elise Debiazi Vargas Longo ${ }^{1 *}\left(\mathbb{\infty}\right.$, Jaime Antonio de Almeida ${ }^{1} \odot$, \\ Gabriel Octávio de Mello Cunha ${ }^{1}[$, Cleiton Junior Ribeiro Lazzari'10

\footnotetext{
${ }^{1}$ Universidade do Estado de Santa Catarina, Centro de Ciências Agroveterinárias, Departamento de Solos e Recursos Naturais, Lages, SC, Brasil. E-mail: agataelongo@gmail.com; jaime.almeida@udesc.br; gabriel.cunha4@gmail.com; cleitonlazzari@yahoo.com.br
}

ABSTRACT: In the Plateau of Lages, intrusions of alkaline and ultrabasic rocks occur, rocks of rare occurrence in Brazil, whose soils derived from them are practically unknown. The study aimed to evaluate the chemical composition, mineralogy, genesis, and classification of the soils developed from the rocks Nepheline Sienite (P1), Volcanic Breccia (P2), Kimberlitic Breccia (P3), Phonolitic Tephrite (P4), and Phonolite (P5). After the morphological description (field) and the collection of soil samples, chemical analyses of the soils, mineralogical of the clay fraction and the total elements of the soils and the corresponding rocks that gave rise to them were carried out. Three Humudepts (Cambissolos), a Hapludolls (Chernossolo), and a Kandiudox (Nitossolo) were identified. Except for the P3 profile, the others are acidic soils, with high levels of exchangeable aluminum, poor in basic cations, with low sum and base saturation, showing a high degree of weathering and strong leaching. In the clay fraction, the presence of 2:1 clay minerals predominated with kaolinite with interlayered hydroxy-Al polymers. The P3 profile showed a slightly acidic reaction, high sum and base saturation, and practically zero exchangeable aluminum, a situation compatible with mineralogy, where trioctahedral vermiculite predominated, revealing that it was a young, slightly weathered soil.

Key words: chemical properties; genesis; mineralogy; soils derived from alkaline and ultrabasic rocks

\section{Mineralogia e gênese de solos desenvolvidos de rochas alcalinas e ultrabásicas do Complexo Alcalino de Lages, Brasil}

RESUMO: No Planalto de Lages, ocorrem intrusões de rochas alcalinas e ultrabásicas, rochas de rara ocorrência no Brasil, cujos solos delas derivados são praticamente desconhecidos. $O$ estudo objetivou avaliar a composição química, a mineralogia, a gênese e a classificação dos solos desenvolvidos das rochas Nefelina Sienito (P1), Brecha Vulcânica (P2), Brecha Kimberlítica (P3), Tefrito Fonolítico (P4) e Fonolito (P5). Para isso, após a descrição morfológica (campo) e a coleta de amostras de solos, procedeu-se as análises químicas dos solos, mineralógicas da fração argila e dos elementos totais dos solos e das rochas correspondentes que Ihes deram origem. Foram identificados três Cambissolos, um Chernossolo e um Nitossolo. Com exceção do perfil P3, os demais são solos ácidos, com elevados teores de alumínio trocável, pobres em cátions básicos, com baixa soma e saturação por bases, evidenciando alto grau de intemperismo e forte lixiviação. Na fração argila predominou a caulinita a presença de argilominerais 2:1 com polímeros hidroxi-Al entrecamadas. 0 perfil P3 apresentou reação ligeiramente ácida, elevada soma e saturação por bases, e alumínio trocável praticamente nulo, situação compatível com a mineralogia, onde predominou a vermiculita trioctaedral, revelando tratar-se de um solo jovem, pouco intemperizado.

Palavras-chave: propriedades químicas; gênese; mineralogia; solos derivados de rochas alcalinas e ultrabásicas

\footnotetext{
* Ágata Elise Debiazi Vargas Longo - E-mail: agataelongo@gmail.com (Corresponding author)

Associate Editor: Clístenes Williams Araújo Nascimento
} 


\section{Introduction}

In the region of Plateau of Lages, SC, lies the Lages Alkaline Complex (Complexo Alcalino de Lages) (CPRM, 2014), a formation composed of intrusions of alkaline and ultrabasic rocks. Although they occupy a small geographic extension, the rocks in the complex are described by Scheibe (1986) as peculiar, with great lithological diversity, where phonolites, nepheline syenites, olivine-melilithites, lamprophyres, in addition to carbonatites, kimberlites, and breccia pipe stand out (Machado et al., 2012).

Characteristics of soils developed from rocks derived from the lava flow from the Serra Geral Formation and Gondwana sedimentary rocks, dominant in the region, are reasonably well known (Ferreira, 2013; Teske et al., 2013). However, for rocks developed from the Lages Alkaline Complex, there is a single study conducted by Ferreira (2013), in which soils derived from phonolite, syenite, and olivine melilithite were studied.

Almeida et al. (2019) mainly identified Cambissolos Húmicos e Háplicos derived from Gondwana sedimentary rocks, all with strongly acidic reaction and low natural fertility, which presented clay mineralogy dominated by kaolinite, but with variable and expressive proportions of 2:1 clay minerals with hydroxy-Al interlayer polymers, (2:1HE) interstratified, and illites. All had very high levels of exchangeable Al (2.20 to $13 \mathrm{cmol}_{\mathrm{c}} \mathrm{kg}^{-1}$ ) and very low sum ( 0.13 to $2.56 \mathrm{cmol}_{\mathrm{c}} \mathrm{kg}^{-1}$ ) and base saturation ( 3 to $20 \%$ ). For soils derived from the lava flow rocks of the Serra Geral Formation (basalt and rhyodacites), the mineralogy is generally similar to soils derived from sedimentary rocks, but with lower crystallinity of kaolinites, lower exchangeable Al contents (1.01 to $2.65 \mathrm{cmol}_{\mathrm{c}} \mathrm{kg}^{-1}$ ) and with slightly higher sum ( 0.13 a $1.02 \mathrm{cmol}_{\mathrm{c}} \mathrm{kg}^{-1}$ ) and base saturation ( 3 to 13\%) values (Teske et al. 2013; Ferreira, 2013; Almeida et al., 2019).

Soils derived from syenite and phonolite studied by Ferreira (2013) had similar mineralogy and chemical properties to those developed from basalt and rhyodacites; on the other hand, the ultrabasic olivine melilithite derivatives stood out for their high natural fertility and mineralogy dominated by vermiculites, but they occupy an inexpressive area in the regional context. However, this suggests that rocks of more basic constitution (alkaline, basic, and ultrabasic), occurring in the Alkaline Complex, can originate more fertile soils compared to those originated from tephrite and nepheline syenite rocks, which in their chemical composition may contain lows contents, mainly of calcium and magnesium oxides.

Several occurrences of phonolites, syenites, and nepheline syenites are currently being identified in prospecting work to use these materials as a potential source of nutrients, in the form of rock powders or soil remineralizers, to supply mainly potassium for plants in alternatives processes for agricultural production (Martins et al., 2015, Ribeiro, 2018). Also, other rocks, not yet properly mapped and classified, have been identified in preliminary field studies, such as trachytes, tephrites, volcanic, and kimberlite breccias, of which details of the chemical and mineralogical composition, as well as the characteristics of the soils derived from them are unknown.

Due to the lack of information on the chemical and mineralogical composition of soils developed from rocks of the Lages Alkaline Complex (Ferreira, 2013), this study aimed to evaluate five soil profiles developed from different rocks of the Complex mentioned above, with alkaline, basic, and intermediate, seeking to characterize in detail the aspects of its genesis, chemical properties, and mineralogical composition, as well as proceeding with the classification of these soils by the Brazilian Classification System (Santos et al., 2018)

\section{Materials and Methods}

According to Köeppen's classification, the climate of the Lages Plateau region, located in Santa Catarina, is of the $\mathrm{Cfb}$ type, humid mesothermal, with cold winter and mild summer, with an average temperature of $16^{\circ} \mathrm{C}$ and average annual rainfall of $1,500 \mathrm{~mm}$. The altitude ranges from 850 to $950 \mathrm{~m}$. The region comprises mixed ombrophilous forest (pine forests), and the phytogeographic classification is of general grasslands associated with subtropical subdeciduous forest and araucaria forest (Santa Catarina, 2015).

The study was carried out with samples of five soil profiles, all developed from rocks of the Lages Alkaline Complex (Nepheline syenite -P1; Kimberlites - P2 and P3); Trachyte - P4, and; Phonolite - P5). The formation comprises alkaline and ultrabasic rocks resulting from late magmatism occurring around 75 Ma BP (Machado et al., 2012). The outcrops of the rocks occur as intrusions amid the Gondwana sedimentary rocks in the vicinity of the Serra Geral Formation escarpments. Also called Domo, or Alkaline District of Lages, this corresponds to a stratigraphic window, where the oldest geological occurrences outcrop at levels similar to the alkaline and ultrabasic, younger ones (Scheibe, 1986; Machado et al., 2012). Such rocks occupy approximately $50 \mathrm{~km}^{2}$ but are dispersed over a larger area, approximately $1200 \mathrm{~km}^{2}$ (Figure 1). Profiles P1, P2, and P5 were in the lower third of the slope in undulating relief; the P3 profile on top of elevation in soft undulating relief; and the $\mathrm{P} 4$ profile in the middle third of the slope in undulating relief.

These soil profiles were selected based on different lithologies that occur in the Lages Alkaline Complex, which may have influenced the genesis and properties of the different soils. The identification of rocks in the field and the respective observation sites were made based on the existing geological literature on the region, notably on the maps prepared by Scheibe (1986), Machado et al. (2012) and crossing with approximate geographic coordinates.

A general and morphological description was made for each profile, and samples were collected from the horizons and the underlying rock, carried out in ravines in road cuts, as described in Santos et al. (2015). All environments were under natural vegetation conditions. Afterward, the soil sample collection (deformed) from each horizon identified in the profile was carried out to subsequently carry out chemical, 

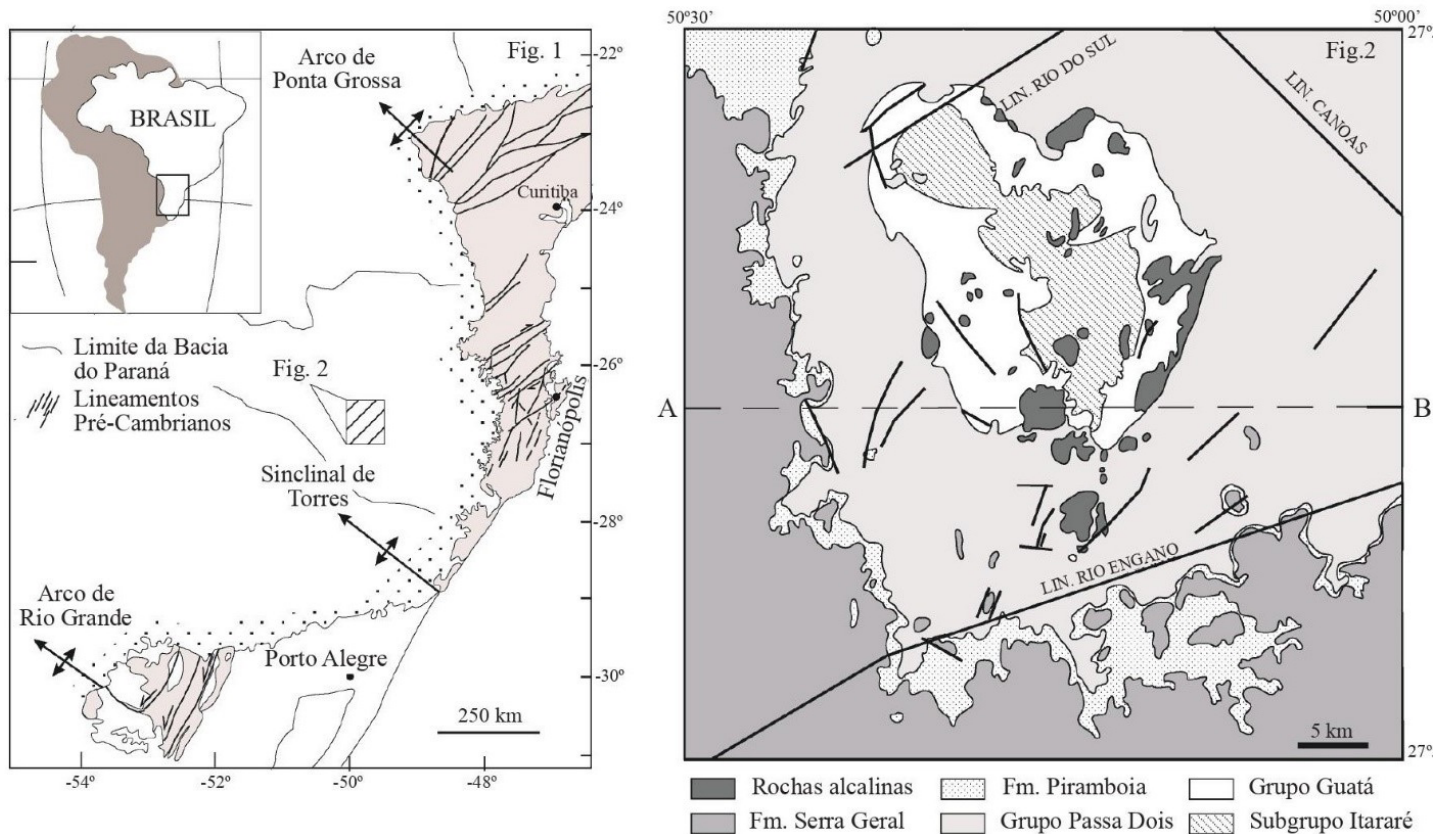

Source: Machado et al. (2012).

Figure 1. Geological map of the alkaline rocks of the Lages Alkaline Complex, SC.

physical, and mineralogical analyses of the soils. Samples of the underlying rocks were also collected for elemental chemical analyses.

After the collections, the soil samples were dried in a forced circulation oven at $60{ }^{\circ} \mathrm{C}$ for 48 hours, chipped with a wooden roller, and sieved in a $2 \mathrm{~mm}$ mesh to separate the air-dried fine earth (ADFE). At ADFE, physical, chemical, and mineralogical analyses were performed.

Physical analyses were performed as described in Embrapa (2017), with some adaptations. In summary, $50 \mathrm{~g}$ of soil were weighed in a $150 \mathrm{~mL}$ snap-cap, then two acrylic pellets and $10 \mathrm{~mL}$ of $1 \mathrm{~mol} \mathrm{~L}^{-1}$ and $75 \mathrm{~mL}$ of distilled water were added. Afterward, the samples were stirred on a horizontal stirrer for $4 \mathrm{~h}$ at $140 \mathrm{rpm}$. After this procedure, the samples were washed with fine jets over a $0.053 \mathrm{~mm}$ sieve to separate the silt and clay from the sand fraction, quantified by weighing after drying at $105^{\circ} \mathrm{C}$.

To quantify the clay, the Bouyoucus densimeter method (Embrapa, 1979) was used. The sand was quantified gravimetrically after drying at $105^{\circ} \mathrm{C}$, and silt was calculated by difference.

In $\mathrm{ADFE}$, the $\mathrm{pH}$ in water and in a $\mathrm{KCl} 1 \mathrm{~mol} \mathrm{~L}^{-1}$ solution was determined by potentiometry in a 1:1 ratio. The exchangeable $\mathrm{Ca}^{2+}, \mathrm{Mg}^{2+}$ e $\mathrm{Al}^{3+}$ contents were extracted with a $1 \mathrm{~mol} \mathrm{~L}^{-1}$ $\mathrm{KCl}$ solution. $\mathrm{Al}^{3+}$ was quantified by neutralization titration with $0.025 \mathrm{~mol} \mathrm{~L}^{-1} \mathrm{NaOH}$, using phenolphthalein (2\%) as an indicator. $\mathrm{Ca}^{2+}$ and $\mathrm{Mg}^{2+}$ were determined by atomic absorption spectrophotometry (model: AAnalyst 200 - Perkin Elmer), using lanthanum oxide to control interferents. $\mathrm{H}+\mathrm{Al}$ was extracted with a $0.5 \mathrm{~mol} \mathrm{~L}^{-1}$ calcium acetate solution buffered at $\mathrm{pH} 7.0$ and quantified by neutralization titration. $\mathrm{K}^{+}$and $\mathrm{Na}^{+}$, extracted by ammonium acetate solution, were quantified by flame photometry. All analyses were performed according to the criteria established in the Soil Analysis Methods Manual (Embrapa, 2017). The total carbon in the soil samples was determined in a Total Carbon Analyzer (TOC) equipment.

Mineralogical analyzes were carried out in the clay fraction, in 2 representative horizons of each profile ( $P$ 1: horizons $\mathrm{B}$ and $\mathrm{C} 1$; P2: BAi and C; P3: $\mathrm{Bi}$ and $\mathrm{Cr}$; P4: Bt1 and BC e; P5: $\mathrm{Bi}$ and $\mathrm{C2}$ ), by X-ray diffraction. For this, the silt and clay from the particle size analysis were separated by successive decantations based on Stokes' Law (Jackson, 1965). Next, the clay samples were saturated with $\mathrm{KCl} 1 \mathrm{~mol} \mathrm{~L}^{-1}$ and $\mathrm{MgCl}_{2} 1$ $\mathrm{mol} \mathrm{L}^{-1}$ solutions separately. Subsequently, excess salts were eliminated using dialysis bags, submerged in distilled water (DW) with previously measured electrical conductivity (EC). The water change was performed every $3 \mathrm{~h}$ until the DW, in which the samples were submerged, reached the initially measured EC (Almeida et al., 2019).

The samples saturated with $\mathrm{K}^{+}$and $\mathrm{Mg}^{2+}$ were analyzed in the form of oriented aggregates, and those of $\mathrm{K}^{+}$were read after drying at room temperature, then heated in an oven to read the samples at $110^{\circ} \mathrm{C}$ and in the muffle to read the samples at the temperatures of 350 and $550{ }^{\circ} \mathrm{C}$. Those with $\mathrm{Mg}^{2+}$ were subjected to air drying $\left(25^{\circ} \mathrm{C}\right)$ and saturation with ethylene glycol vapor (ETG) at $60^{\circ} \mathrm{C}$ for $48 \mathrm{~h}$.

Mineralogical analyses were performed using a Philips $X$-ray diffractometer, model PW 3710, equipped with a copper tube, with a $\theta / 2 \theta$ compensation angle, vertical goniometer, and a graphite monochromator, with angular variation from 3 to 42 for the samples of oriented clay, with an angular velocity of $0.02^{\circ} 2 \theta / \mathrm{s}$, in step mode, with a reading time of 0.5 seconds per step. To identify the minerals, the parameters of Brown \& Brindley (1980), Whittig \& Allardice (1986) were used, as well as specific literature indicated in the text, when applicable. For semi-quantification of clay minerals, the 
Panalytical X'Pert High Score Plus software (3.0) was used, measuring the relative areas of the main reflections of each identified mineral.

Elemental analyses were performed using the X-ray fluorescence technique, with the elements expressed as oxides. Such analyses were carried out in the clay fraction powder of the selected horizons of each soil profile, previously mentioned, as well as in the rock powder. These analyzes were used to quantify the oxides in the source material of each soil and in the clay fraction to calculate the Ki index, obtained by the formula: $\mathrm{Ki}=\left(\mathrm{SiO}_{2} / \mathrm{Al}_{2} \mathrm{O}_{3}\right) \times 1.7$ (Silva, 2020).

The clay fraction and rock samples were ground in an agate mortar until the entire content passed through a $0.053 \mathrm{~mm}$ sieve and homogenized. Then, the samples were placed in a cylindrical sampler, with the bottom closed with a polyester film ("mylar") of $3.6 \mu \mathrm{m}$. A compact X-ray fluorescence (XRF) spectrometry equipment, model Epislon 3 from Panalytical was used. To calibrate the equipment, the OMNIAN application (Epsilon software package) was used, which are standard samples in the format of cast pellets, analyzing 24 elements simultaneously.

\section{Results and Discussion}

\section{Chemical composition of rocks}

The $\mathrm{SiO}_{2}$ content evidenced in the phonolite rock powder (P5) was within the expected range (52 to $65 \%$ ), with a value of $55.11 \%$, placing this rock in the intermediate group. The $\mathrm{CaO}$ and $\mathrm{MgO}$ contents for this rock are low, totaling $1.86 \%$. On the other hand, those of $\mathrm{Na}_{2} \mathrm{O}$ and $\mathrm{K}_{2} \mathrm{O}$ are high, as well as those of aluminum. The same interpretation performed for the phonolite can be admited for the nepheline syenite $(\mathrm{P} 1)$, probably because it is the intrusive correspondent of the phonolite. However, it should be noted that the $\mathrm{SiO}_{2}$ contents (51.20\%) (Table 1) were slightly below those commonly reported for this rock, classified as intermediate. Then, these results confirm that based on the general composition, the classification of these two rocks as alkaline. Thus, the composition of these two rocks is compatible with the values normally referenced in studies carried out by Scheibe (1986), Le Maitre (2002), and Motoki et al. (2013).

For P2, the elemental composition of the rock collected in this profile shows high $\mathrm{SiO}_{2}$ content $(56.67 \%$ ) (intermediate group), very low levels of magnesium oxide (0.4\%), chromium and strontium, and abnormal aluminum content (Table 1).
Nevertheless, it had morphological similarity to kimberlites or kimberlite breccias. Therefore, given the elemental composition observed, it was classified as a volcanic breccia, as also evidenced by Scheibe (1986).

Regarding the rock collected in P3, the elemental composition shows a relatively high content of $\mathrm{SSiO}_{2}(47 \%)$, high contents of $\mathrm{CaO}$ and $\mathrm{MgO}$ (sum of these oxides around $22 \%)$, titanium, chromium, strontium, and nickel. However, the $\mathrm{CaO}$ content exceeded that of $\mathrm{MgO}$ (Table 1). Although there was a great morphological similarity between this rock and a kimberlite, it differed from this rock by the higher contents of $\mathrm{SiO}_{2}$ and $\mathrm{MgO}$ and the normal pattern of most kimberlites studied by Costa et al. (1997). Given these results, the rock was classified as a kimberlite breccia.

The chemical composition of the rock collected in P4 has a $\mathrm{SiO}_{2}$ content of around $49 \%$. Therefore, it belongs to the basic group. Furthermore, this rock has high contents of $\mathrm{K}, \mathrm{Ca}, \mathrm{Al}$, and $\mathrm{P}_{2} \mathrm{O}_{5}$ oxides, relatively high $\mathrm{Na}$, and low trace elements. Furthermore, based on the chemical composition data of samples collected in the Lages region by Scheibe (1986) and Aumond \& Scheibe (1996), the selected rock would fit better as a porphyritic nepheline syenite. However, for the first author, this rock would be located in the field of phonolitic tephrites. The elementary composition of a tephrite analyzed by Comin-Chiaramonti et al. (2001) in the region of Lages is very similar to the composition of the studied rock.

Similar results regarding the classification of rocks collected in the Lages Alkaline Complex, evidenced in this study, were also verified by Scheibe (1986) and Roldan (2007). After evaluating some rocks from the aforementioned Complex, these authors separated them into leucocratic alkaline (phonolites, porphyritic phonolites, analcime, trachytes, and porphyritic nephelines syenites), alkaline ultrabasic (olivine melilithites and lamprophyres), carbonatites, kimberlites, and volcanic breccias. In addition, the elemental composition of the rocks based on $\mathrm{SiO}_{2}$ contents are in accordance with those reported by Leinz \& Amaral (1985) and Ferreira (2013), although this study found higher levels of basic oxides when compared with those obtained by the last author.

\section{Morphology, physical, and chemical properties of soils}

All soils studied, except for P1, showed high levels of carbon in the superficial horizons (Table 2), forming relatively thick and dark A horizons (P1: $49 \mathrm{~cm}$; P2: $40 \mathrm{~cm}$; P3: $25 \mathrm{~cm}$; P4: $60 \mathrm{~cm}$ and $P 5: 38 \mathrm{~cm}$ ), which can be attributed to the cold and

Table 1. Elements in the form of oxides, by X-Ray fluorescence, of the powder of the rocks of profiles P1 (nepheline syenite), P2 (volcanic breccia), P3 (kimberlite breccia), P4 (trachyte), and P5 (phonolite).

\begin{tabular}{|c|c|c|c|c|c|c|c|c|c|c|c|c|}
\hline \multirow{2}{*}{ Sample } & $\mathrm{Na}_{2} \mathrm{O}$ & $\mathrm{K}_{2} \mathrm{O}$ & $\mathrm{CaO}$ & $\mathrm{MgO}$ & $\mathrm{Al}_{2} \mathrm{O}_{3}$ & $\mathrm{SiO}_{2}$ & $\mathbf{P}_{2} \mathbf{O}_{5}$ & $\mathrm{TiO}_{2}$ & $\mathrm{Cr}_{2} \mathrm{O}_{3}$ & $\mathrm{NiO}$ & $\mathrm{CuO}$ & $\mathrm{Sr}$ \\
\hline & \multicolumn{12}{|c|}{ (\%) } \\
\hline P1 & 2.47 & 5.08 & 2.98 & 1.78 & 28.48 & 51.20 & 0.61 & 0.64 & 0.02 & 0.006 & - & 0.12 \\
\hline $\mathrm{P} 2$ & 4.30 & 8.03 & 1.74 & 0.41 & 23.34 & 56.67 & 0.40 & 0.25 & 0.01 & - & - & 0.05 \\
\hline P4 & 2.47 & 5.27 & 6.71 & 1.33 & 22.13 & 48.73 & 1.30 & 1.46 & - & - & 0.003 & 0.36 \\
\hline P5 & - & 6.7 & 1.44 & 0.42 & 28.66 & 55.11 & 0.51 & 0.59 & 0.01 & 0.001 & - & 0.04 \\
\hline
\end{tabular}

- not detected. 
humid climate of the region, which favors its accumulation in the soil (Almeida et al., 2018; 2019). The colors were dark brown and dark grayish brown on this horizon, while on the B horizon, brown and strong brown colors predominated. Except for the P4 profile, the B horizon of the other soils showed little thickness (P1: $110 \mathrm{~cm}$; P2: $103 \mathrm{~cm}$; P3: $80 \mathrm{~cm}$; P4: $150+$ and P5: $72 \mathrm{~cm}$ ) (Table 2), and variations thereof in the lateral extension, a fact that, together with the low textural contrast and absence or low expression of waxiness, indicated the presence of an incipient type B subsuperficial diagnostic horizon.

As for chemical properties, all soils, except for Profile 3 , showed acid reaction and low natural fertility, with low $\mathrm{pH}$ values in water and $\mathrm{KCl} 1 \mathrm{~mol} \mathrm{~L}^{-1}$, low basic cations, and high $\mathrm{Al}^{3+}$ and $\mathrm{H}+\mathrm{Al}$ contents, resulting in high aluminum saturation, being low, therefore, the sum and base saturation, characterizing dystrophic or aluminum soils (Table 2).

The $\mathrm{pH}$ in $\mathrm{KCl} 1 \mathrm{~mol} \mathrm{~L}^{-1}$ was always lower than the $\mathrm{pH}$ in water, resulting in a negative net charge balance, which was confirmed by the relatively high values of $\mathrm{CEC}$ at $\mathrm{pH}$ 7.0, clay fraction activity, and mineralogy of the clay fraction, as shown below. Nevertheless, except for the P3 profile, the other soils presented clay fraction activity values below $27 \mathrm{cmol}_{\mathrm{c}} \mathrm{kg}^{-1}$, characterizing soils with low activity (Tb) (Table 2).

The most acidic profiles, P1, P2, and P5 (compared to the other profiles), had a high exchangeable aluminum content, with an average above $4 \mathrm{cmol}_{\mathrm{c}} \mathrm{kg}^{-1}$, with aluminum saturation above $60 \%$. Conversely, profiles $\mathrm{P} 3$ and $\mathrm{P} 4$ had lower aluminum values, being inexpressive in $\mathrm{P} 3$ (Table 2). Such properties are similar to the vast majority of soils developed from basalt, rhyodacite, and sedimentary rocks occurring in the Planalto Sul Catarinense, verified by several authors (Ferreira, 2013; Teske et al., 2013; Almeida et al., 2019).

In general, the high acidity observed in profiles P1, P2, $\mathrm{P} 4$, and $\mathrm{P} 5$ ( $\mathrm{pH}$ ranging from 4.31 to 5.28 ) can be explained by the constant presence of $\mathrm{H}^{+}$ions from the dissociation of carbonic acid, from the degradation of clay minerals, and the biodegradation of organic matter (OM). In natural environments and a humid climate, with a lack of basic cations, OM's decomposition (biodegradation) is slow. It results in the release of greater amounts of organic acids into the soils, increasing the amounts of $\mathrm{H}^{+}$in the CEC of the soils, increasing even more soil buffering (Lu et al., 2015; Jiang et al., 2018). Therefore, the soil developed from the kimberlite

Table 2. Chemical and physical attributes of soils.

\begin{tabular}{|c|c|c|c|c|c|c|c|c|c|c|c|c|c|c|c|c|c|c|c|}
\hline \multirow{2}{*}{ H. (1) } & \multirow{2}{*}{$\begin{array}{c}\text { Depth }^{(2)} \\
\text { (cm) }\end{array}$} & Clay ${ }^{(3)}$ & Silt ${ }^{(4)}$ & Sa. ${ }^{(5)}$ & $\mathrm{TC}^{(6)}$ & \multicolumn{2}{|c|}{$\mathrm{pH}(1: 1)$} & $\mathrm{Al}^{3+}$ & $\mathrm{H}+\mathrm{Al}$ & $\mathrm{Ca}^{2+}$ & $\mathrm{Mg}^{2+}$ & $\mathbf{K}^{+}$ & $\mathrm{Na}^{+}$ & $S^{(7)}$ & $T^{(8)}$ & $t^{(9)}$ & $\mathrm{CA}^{(10)}$ & $V^{(11)}$ & $\mathrm{m}^{(12)}$ \\
\hline & & \multicolumn{4}{|c|}{$\left(\mathrm{g} \mathrm{kg}^{-1}\right)$} & Water & $\mathrm{KCl}$ & \multicolumn{10}{|c|}{$\left(\mathrm{cmol}_{\mathrm{c} \mathrm{kg}}{ }^{-1}\right)$} & \multicolumn{2}{|c|}{$(\%)$} \\
\hline \multicolumn{20}{|c|}{ Profile P1 - Nepheline Syenite - Cambissolo Háplico Alumínico típico } \\
\hline A & $0-17$ & 520 & 162 & 318 & 14.5 & 4.72 & 3.95 & 4.41 & 9.64 & 0 & 0.063 & 0.009 & 0.16 & 0.23 & 9.88 & 4.64 & 19.00 & 2 & 95 \\
\hline$A B$ & $17-49$ & 640 & 126 & 234 & 19.3 & 4.41 & 3.85 & 5.87 & 10.56 & 0 & 0.063 & 0.009 & 0.18 & 0.26 & 10.82 & 6.13 & 16.91 & 2 & 96 \\
\hline BA & $49-61$ & 660 & 127 & 213 & 14.5 & 4.31 & 4.05 & 6.66 & 10.02 & 0 & 0.043 & 0.008 & 0.18 & 0.23 & 10.26 & 6.90 & 15.54 & 2 & 96 \\
\hline $\mathrm{B}$ & $61-92 / 95$ & 540 & 197 & 263 & 8.0 & 4.47 & 3.92 & 8.45 & 11.73 & 0 & 0.057 & 0.012 & 0.17 & 0.24 & 11.97 & 8.69 & 22.17 & 2 & 97 \\
\hline$B C$ & $92 / 95-110$ & 420 & 208 & 372 & 5.0 & 4.62 & 3.83 & 9.01 & 12.90 & 0 & 0.093 & 0.022 & 0.18 & 0.29 & 13.20 & 9.31 & 31.43 & 2 & 97 \\
\hline $\mathrm{C} 1$ & $110-140$ & 420 & 188 & 392 & 3.7 & 4.96 & 4.10 & 6.33 & 9.34 & 0 & 0.050 & 0.014 & 0.16 & 0.23 & 9.57 & 6.57 & 22.78 & 2 & 96 \\
\hline \multicolumn{20}{|c|}{ Profile P2 - Volcanic Breccia - Cambissolo Háplico Alumínico típico } \\
\hline $\mathrm{A} 1$ & $0-13$ & 420 & 353 & 227 & 33.4 & 5.28 & 3.99 & 2.25 & 8.17 & 0.01 & 0.25 & 0.87 & 0.04 & 1.17 & 9.34 & 3.42 & 22.24 & 12 & 66 \\
\hline $\mathrm{A} 2$ & $13-40$ & 520 & 269 & 211 & 20.8 & 5.25 & 3.91 & 3.54 & 9.18 & 0.01 & 0.06 & 0.99 & 1.17 & 2.23 & 11.41 & 5.78 & 21.95 & 20 & 61 \\
\hline $\mathrm{BAi}$ & $40-53 / 63$ & 560 & 247 & 193 & 12.4 & 5.02 & 3.97 & 4.82 & 9.0 & 0.01 & 0.04 & 0.32 & 0.02 & 0.37 & 9.37 & 5.19 & 16.74 & 4 & 93 \\
\hline$B C$ & $53 / 63-103$ & 560 & 244 & 196 & 7.5 & 5.23 & 4.03 & 6.54 & 12.16 & 0.01 & 0.02 & 0.30 & 0.09 & 0.42 & 12.59 & 6.97 & 22.48 & 3 & 94 \\
\hline C & $82 / 103-85 / 95 / 120$ & 480 & 300 & 220 & 6.6 & 5.07 & 3.86 & 9.97 & 14.74 & 0.01 & 0.04 & 0.26 & 0.03 & 0.65 & 15.39 & 10.63 & 32.06 & 4 & 94 \\
\hline CR & 85/95/120-160+ & 340 & 472 & 188 & 3.1 & 5.16 & 3.92 & 10.03 & 14.97 & 0.01 & 0.05 & 0.36 & 0.44 & 0.85 & 15.83 & 10.89 & 46.55 & 5 & 92 \\
\hline \multicolumn{20}{|c|}{ Profile P3 - Kimberlite Breccia - Chernossolo Háplico Órtico típico } \\
\hline A1 & $0-9$ & 400 & 355 & 255 & 47.7 & 6.39 & 4.73 & 0.06 & 6.4 & 7.8 & 3.86 & 0.48 & 0.06 & 12.19 & 18.6 & 11.81 & 46.60 & 65 & 1 \\
\hline $\mathrm{A} 2$ & $9-22 / 25$ & 400 & 385 & 215 & 47.0 & 6.95 & 4.91 & 0.03 & 5.6 & 6.35 & 4.35 & 0.18 & 0.08 & 10.96 & 16.57 & 9.56 & 41.42 & 66 & 0 \\
\hline $\mathrm{Bi}$ & $22 / 25-50$ & 440 & 326 & 234 & 20.1 & 6.66 & 5.24 & 0.0 & 3.85 & 3.52 & 6.93 & 0.22 & 0.12 & 10.81 & 14.66 & 10.81 & 33.33 & 74 & 0 \\
\hline$B C$ & $50-80$ & 440 & 399 & 161 & 8.2 & 7.5 & 5.15 & 0.05 & 3.27 & 5.46 & 16.33 & 0.36 & 0.24 & 22.40 & 25.68 & 22.46 & 58.36 & 87 & 0 \\
\hline $\mathrm{C} 1$ & $80-110$ & 420 & 399 & 181 & 6.0 & 7.11 & 4.19 & 0.32 & 3.69 & 4.44 & 18.10 & 0.42 & 0.18 & 24.16 & 27.85 & 24.48 & 66.30 & 87 & 1 \\
\hline $\mathrm{C} 2$ & $110-127$ & 400 & 366 & 234 & 3.6 & 7.05 & 4.32 & 0.33 & 3.33 & 4.35 & 17.73 & 0.29 & 0.19 & 22.58 & 25.91 & 22.91 & 64.76 & 87 & 1 \\
\hline CR & $127-140+$ & 340 & 376 & 384 & 3.4 & 6.98 & 4.73 & 0.11 & 2.23 & 4.94 & 18.67 & 0.31 & 0.31 & 24.25 & 26.48 & 24.37 & 77.90 & 92 & 0 \\
\hline \multicolumn{20}{|c|}{ Profile P4 - Phonolitic Tephrite - Nitossolo Bruno Distrófico húmico } \\
\hline A1 & $0-8 / 10$ & 500 & 386 & 114 & 59.9 & 5.23 & 4.62 & 0.88 & 10.26 & 4.04 & 0.58 & 1.10 & 0.17 & 5.9 & 16.16 & 5.90 & 32.3 & 36 & 15 \\
\hline $\mathrm{A} 2$ & $8 / 10-36$ & 620 & 293 & 87 & 29.1 & 5.43 & 4.42 & 1.61 & 9.21 & 2.29 & 0.28 & 0.84 & 0.15 & 3.57 & 12.78 & 5.18 & 20.62 & 28 & 31 \\
\hline $\mathrm{Ae}$ & $36-52 / 60$ & 700 & 145 & 55 & 22.5 & 5.45 & 4.0 & 3.04 & 10.24 & 2.55 & 0.20 & 0.57 & 0.15 & 3.48 & 13.72 & 6.53 & 17.15 & 25 & 47 \\
\hline BA & $52 / 60-72 / 80$ & 720 & 122 & 58 & 14.5 & 5.43 & 3.90 & 3.37 & 8.42 & 1.23 & 0.15 & 0.38 & 0.14 & 1.91 & 10.33 & 5.29 & 12.60 & 18 & 64 \\
\hline Bt1 & $72 / 80-90 / 105$ & 740 & 195 & 65 & 10.9 & 5.58 & 3.72 & 3.67 & 9.04 & 0.5 & 0.07 & 0.24 & 0.18 & 1.0 & 10.04 & 4.67 & 13.57 & 10 & 79 \\
\hline Bt2 & $90 / 105-130$ & 760 & 165 & 75 & 6.5 & 5.51 & 3.78 & 3.93 & 9.05 & 0.28 & 0.06 & 0.20 & 0.18 & 0.72 & 9.78 & 4.65 & 12.86 & 7 & 84 \\
\hline $\mathrm{BC}$ & $130-150+$ & 820 & 106 & 74 & 7.2 & 5.65 & 3.83 & 3.98 & 9.25 & 0.33 & 0.07 & 0.22 & 0.15 & 0.78 & 10.03 & 4.77 & 12.23 & 8 & 84 \\
\hline \multicolumn{20}{|c|}{ Profile P5 - Phonolite - Cambissolo Húmico Alumínico típico } \\
\hline A1 & $0-12$ & 480 & 421 & 99 & 33.3 & 4.86 & 3.85 & 3.94 & 11.39 & 1.08 & 0.10 & 0.73 & 0.13 & 2.06 & 13.45 & 6.00 & 28.02 & 15 & 66 \\
\hline A2 & $12-38$ & 500 & 408 & 92 & 45.9 & 4.7 & 3.95 & 6.05 & 12.76 & 0.24 & 0.14 & 0.24 & 0.13 & 0.77 & 13.53 & 6.82 & 27.07 & 6 & 89 \\
\hline $\mathrm{Bi}$ & $38-52$ & 500 & 362 & 138 & 8.2 & 4.75 & 3.72 & 7.35 & 12.0 & 0.016 & 0.08 & 0.36 & 1.07 & 1.54 & 13.55 & 8.90 & 27.10 & 11 & 83 \\
\hline$B C$ & $52-72$ & 500 & 356 & 144 & 6.7 & 4.75 & 3.80 & 7.22 & 10.20 & 0 & 0.04 & 0.29 & 1.16 & 1.50 & 11.71 & 8.73 & 23.42 & 13 & 83 \\
\hline $\mathrm{C} 1$ & $72-113$ & 480 & 415 & 105 & 4.0 & 4.80 & 3.73 & 6.04 & 9.18 & 0 & 0.02 & 0.06 & 0.87 & 0.96 & 10.14 & 7.01 & 21.13 & 9 & 86 \\
\hline $\mathrm{C} 2$ & $113-120+$ & 480 & 352 & 168 & 3.2 & 4.71 & 3.88 & 7.02 & 10.76 & 0 & 0.02 & 0.08 & 0.83 & 0.93 & 11.70 & 7.96 & 24.37 & 8 & 88 \\
\hline
\end{tabular}


breccia, compared to the others, is more fertile, with high $\mathrm{pH}$ values, basic cation contents, base sum, and saturation and low $\mathrm{Al}^{3+}, \mathrm{H}+\mathrm{Al}$ in \% (Table 2), similar to the soil derived from olivine melilithite studied by Ferreira (2013) in a relatively close location.

As for the particle size, all soils had a clayey or very clayey texture on the B horizon. The lowest clay contents were observed in the P3 profile (Table 2), developed from kimberlite breccia (Table 1), which presented features of a lower degree of development in field observations, indicated by the expressive presence of phlogopite-type micas in most of the horizons, as will be shown below.

In the $\mathrm{P} 1$ and $\mathrm{P} 2$ profiles, the Ki value (Table 3 ) ranged from 2.3 to 2.4 in the B horizon slightly above, therefore, the $\mathrm{Ki}$ of kaolinite, this being attributed to the probable presence of 2:1 layer clay minerals in association with kaolinite, which is consistent with the relatively high activity values of the clay fraction (Table 2). At P3, Ki values were around 3.0 to 3.9 for subhorizons $B$, with an increase in underlying $\mathrm{Cr}$, also suggesting the expressive participation of 2:1 clay minerals in the mineralogical composition of this soil, also being compatible with the high activity values of the clay fraction (Table 2).

Still, in relation to $\mathrm{Ki}$, in $\mathrm{P} 4$, it was verified that it was around 2.2 for the main subhorizons of $B$ with a slight increase in the underlying $B C$. This result suggests the predominance of kaolinite with little participation of clay minerals in the 2:1 layer, such interpretation being consistent with the low clay activity values (Table 2). At P5, the Ki was around 2.6 on the $\mathrm{B}$ horizon, confirming the previous idea regarding the likely

Table 3. Ki index determined in the clay and Fe oxide fraction of ADFE by X-Ray Fluorescence, and reflection area around $1.4 \mathrm{~nm}$ (A14), representative of 2:1 minerals (vermiculite or smectite); at $1.0 \mathrm{~nm}$ (A10), from mica or illite; and $0.72 \mathrm{~nm}$ (A7), from kaolinite, relative to the total areas (At) of these reflections.

\begin{tabular}{|c|c|c|c|c|c|c|}
\hline \multirow{2}{*}{ Profile } & \multirow{2}{*}{ Horizon } & \multirow{2}{*}{$\begin{array}{r}\mathrm{Ki}_{\mathrm{XRF}} \\
\text { clay } \\
\end{array}$} & \multirow{2}{*}{$\begin{array}{l}\mathrm{Fe}_{2} \mathrm{O}_{3} \\
\text { ADFE }\end{array}$} & $A_{14} / A t$ & $A_{10} / A t$ & $A_{7} / A t$ \\
\hline & & & & \multicolumn{3}{|c|}{$02 \theta$} \\
\hline \multirow{3}{*}{ P1 } & $A B$ & 2.21 & 7.57 & 0.24 & 0.04 & 0.72 \\
\hline & B & 2.27 & 7.67 & 0.52 & 0.07 & 0.41 \\
\hline & C1 & 2.29 & 7.24 & 0.41 & 0.03 & 0.56 \\
\hline \multirow{4}{*}{ P2 } & $\mathrm{A} 2$ & 2.54 & 6.34 & 0.03 & 0.43 & 0.42 \\
\hline & Bai & 2.42 & 7.22 & 0.15 & 0.25 & 0.60 \\
\hline & $C$ & 2.39 & 7.72 & 0.21 & 0.19 & 0.60 \\
\hline & $\mathrm{Cr}$ & 2.44 & 5.29 & 0.41 & 0.18 & 0.42 \\
\hline \multirow{4}{*}{ P3 } & $\mathrm{A} 2$ & 3.42 & 14.55 & 0.41 & 0.28 & 0.30 \\
\hline & $\mathrm{Bi}$ & 3.02 & 18.81 & 0.68 & 0.05 & 0.27 \\
\hline & C1 & 3.94 & 18.25 & 0.98 & 0.01 & 0.01 \\
\hline & $\mathrm{Cr}$ & 4.70 & 16.94 & - & - & - \\
\hline \multirow{4}{*}{ P4 } & $\mathrm{A} 2$ & 2.52 & 10.8 & 0.38 & 0.02 & 0.61 \\
\hline & $\mathrm{Ae}$ & 2.30 & 11.96 & 0.30 & 0.02 & 0.68 \\
\hline & Bt1 & 2.25 & 11.06 & 0.50 & 0.05 & 0.45 \\
\hline & $B C$ & 2.23 & 11.42 & 0.30 & 0.04 & 0.67 \\
\hline \multirow{3}{*}{ P5 } & $\mathrm{A} 2$ & 2.65 & 6.99 & 0.51 & - & 0.56 \\
\hline & $\mathrm{Bi}$ & 2.58 & 8.21 & 0.50 & 0.04 & 0.46 \\
\hline & $\mathrm{C} 2$ & 2.67 & 2.62 & 0.24 & 0.07 & 0.69 \\
\hline
\end{tabular}

- not detected. contribution of expandable 2:1 clay minerals in this soil. These results are similar to those obtained by Ferreira (2013) for soils derived from basalt and rocks from the Lages Alkaline Complex. Further details of mineralogical analyses are discussed below.

Regarding the $\mathrm{Fe}_{2} \mathrm{O}_{3}$ contents of ADFE, the results indicate hypoferric soils for $\mathrm{P} 1$ and $\mathrm{P} 2$. Likewise, for hypoferric $\mathrm{P} 3$ and mesoferric $\mathrm{P} 4$ and $\mathrm{P} 5$, according to the criteria established by Santos et al. (2018).

Based on the set of observed characteristics, the superficial diagnostic horizon of the soils corresponding to profiles $P 1$ and $\mathrm{P} 2$ were identified as prominent $A$ that of profiles $P 4$ and $P 5$ as humic and that of P3 as chernozemic $A$. The subsurface diagnostic horizon of the P1, P2, P3, and P5 profiles was identified as incipient $B$, while that of the $P 4$ profile as a nitic $B$ horizon. Based on the other diagnostic attributes, the profiles were classified respectively, according to SiBCS (Santos et al., 2018) and Soil Taxonomy (Soil Survey Staff, 2014) as: Cambissolo Háplico Aluminico típico (Humudepts) (P1 and P2 profiles), Chernossolo Háplico Órtico típico (Hapludolls) (P3 profile), Nitossolo Bruno Distrófico húmico (Kandiudox) (P4 profile), and Cambissolo Húmico Alumínico típico (Humudepts) (P5 profile).

Mineralogical characteristics of the clay fraction of the studied profiles

Profile 1 - Nepheline Syenite

In the typical Cambissolo Háplico Aluminico típico (Humudepts), developed from nepheline syenite, the horizon diffractograms indicate similar mineralogy along with the profile, composed of kaolinite, with probable 2:1 layer interstratification, expandable 2:1 clay minerals, and micas and/or illites, variations occur mainly in the proportions of expandable 2:1 layer clay minerals (Figure 2A and 2B).

The dominant mineral in this soil is kaolinite, identified by its most intense reflections at 0.720 and $0.357 \mathrm{~nm}$, followed by the least intense at $0.237 \mathrm{~nm}$, in magnesium samples $(\mathrm{Mg}$ 25), whose main reflection area (001) was greater than that of the other minerals individually, being confirmed by their disappearance in the sample saturated with $\mathrm{K}$ and heated to $550{ }^{\circ} \mathrm{C}$ (Dixon, 1989). The base of these reflections is wide, and the peaks are asymmetrical towards the lowest $2 \theta$ angles, in the case of the reflection of the 001 plane, and towards higher angles in the case of the 002, indicative of minerals with low structural order, of low crystallinity (Aparicio \& Galán, 1999). The asymmetry in the 0.720 and $0.357 \mathrm{~nm}$ peaks can also indicate the interstratification of 2:1 layers in the kaolinite crystals (Bortoluzzi et al., 2007). Nevertheless, it was not possible to identify whether it was a kaolinite-smectite (KS) or another interstratified.

Reflections around $1.47 \mathrm{~nm}$ in samples saturated with $\mathrm{Mg}$ at $25^{\circ} \mathrm{C}$, which did not undergo expansion with ETG (ethylene glycol), indicated the possibility of smectite or vermiculite (Barnhisel \& Bertsch, 1989). However, in samples saturated with $\mathrm{K}$, the layers do not undergo complete contraction at 10 $\AA$ After heating to 350 degrees (K 350 ), maintaining a reflection 
A. P1 - B

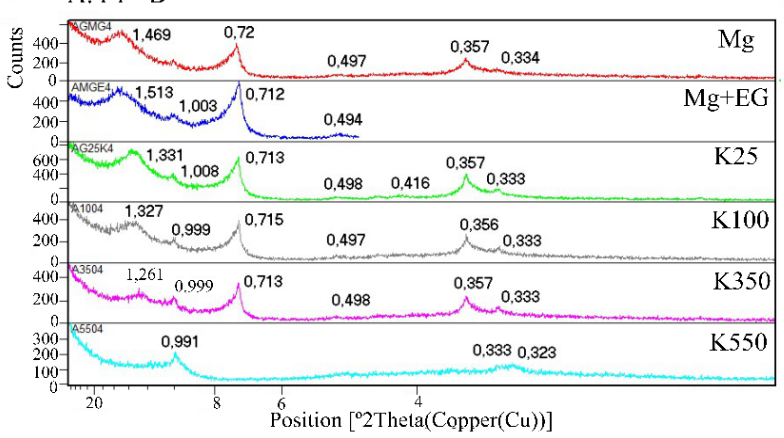

C. P2 - BAi

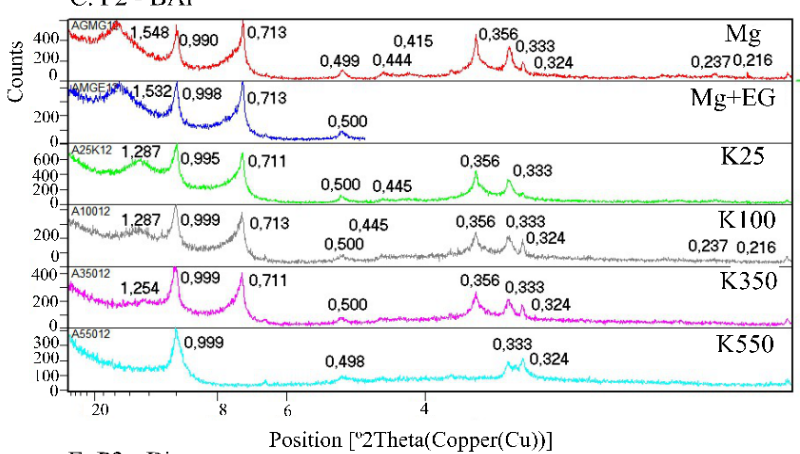

E. P3 - Bi

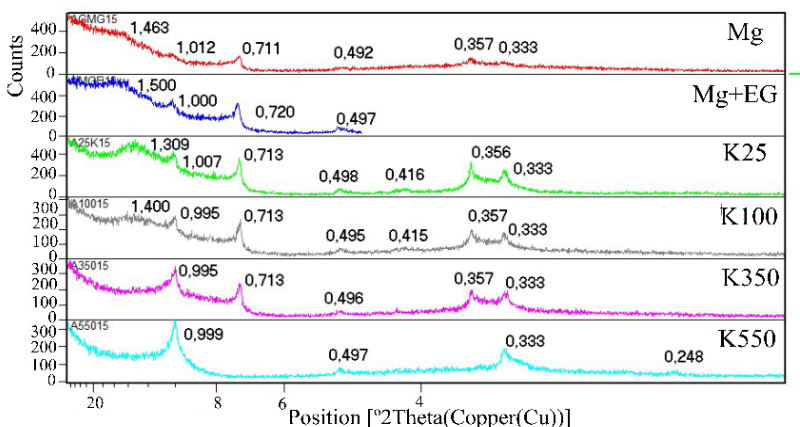

G. P4 - Bt 1

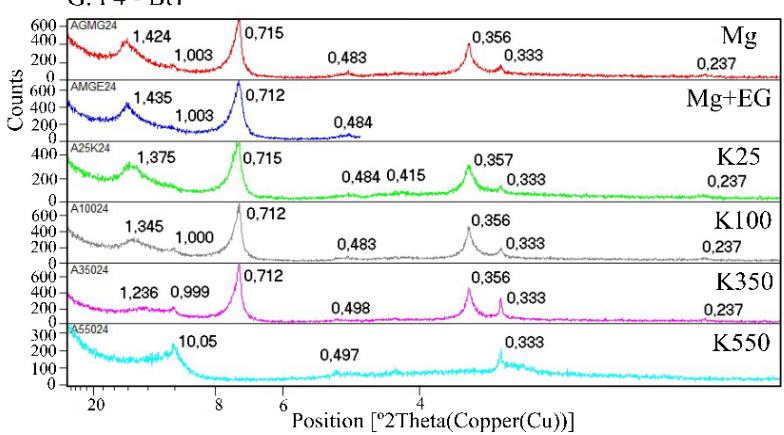

1. $\mathrm{P} 5$ - Bi

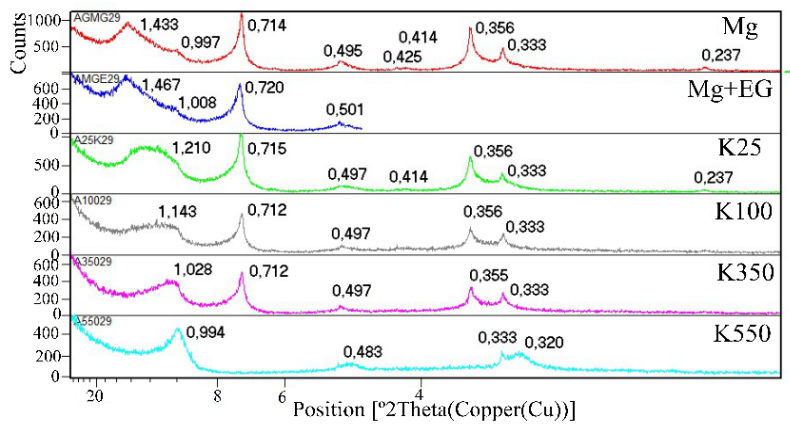

B. Pl - C1

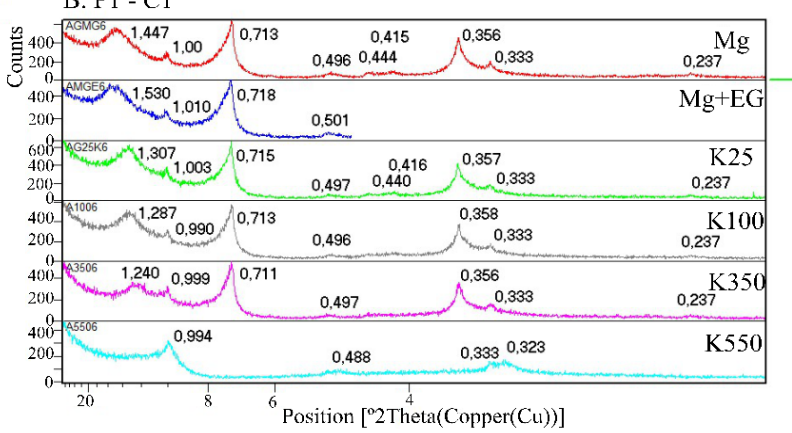

D. $\mathrm{P} 2-\mathrm{C}$

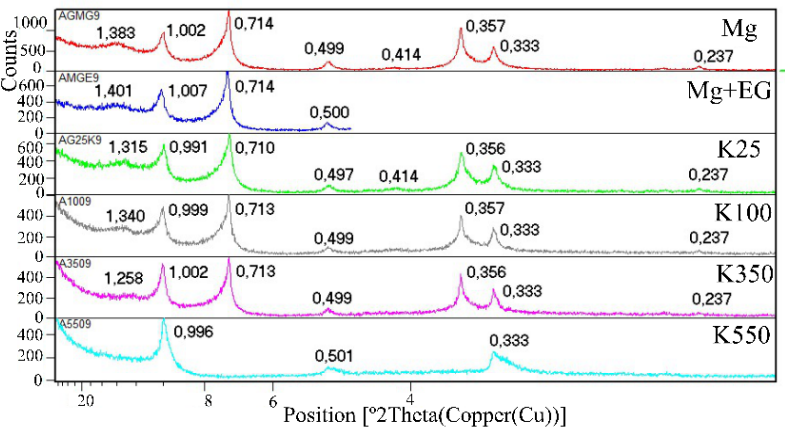

F. P3 - CR

$1,1,554$
0,720

H. P4 - BC

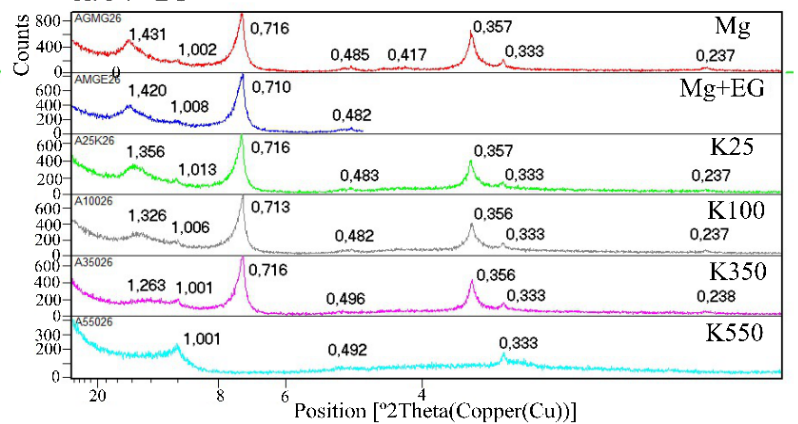

J. P5 - C2

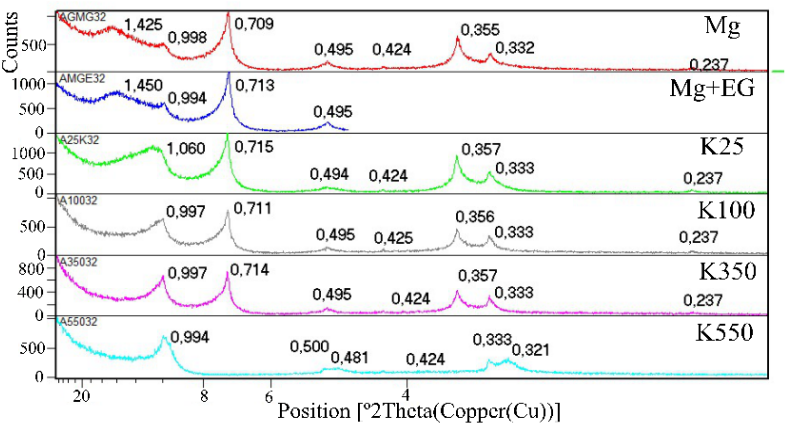

Figure 2. Diffractograms of the clay fraction of profiles $P 1$ ( $A$ and B), $P 2$ ( $C$ and $D), P 3$ (E and F), P4 (G and H), and P5 (I and J), with magnesium at $25^{\circ} \mathrm{C}(\mathrm{Mg})$ and $\mathrm{Mg}$ plus ethylene glycol (Mg+EG), and with potassium at $25^{\circ} \mathrm{C}(\mathrm{K} 25), 100{ }^{\circ} \mathrm{C}(\mathrm{K} 100), 350^{\circ} \mathrm{C}$ (K350), and $550^{\circ} \mathrm{C}$ (K550) for selected horizons. 
with a value close to $1.25 \mathrm{~nm}$, revealing that they are 2:1 layer clay minerals with hydroxy-Al polymers in the interlayers, probably vermiculites (VHE) (Barnhisel \& Bertsch, 1989). Such minerals have been frequently found in the clay fraction of soils in the region of Lages (Almeida et al. 2018; 2019).

Micas and/or illites are of low expression, confirmed by reflections of $1.012,0.500$, and $0.334 \mathrm{~nm}$. This pattern is maintained along with the profile but with lower intensity of kaolinite and illite reflections on the $B$ and $C 1$ horizons. The reflections around 0.415 and $0.417 \mathrm{~nm}$ indicate the presence of goethite, responsible for the predominant brownish color in the soil.

The still expressive presence of 2:1HE layer clay minerals also reveal the occurrence of partial bissilization processes, probably occurred in a drier past climate, which in the current wetter and colder climate, suffered intercalation with hydroxy-Al polymers in the interlayers, making them more thermodynamically stable (Karatahanasis et al., 1983), and so they are still preserved in the soil. The mineralogical composition observed is compatible with the clay activity values (Table 2) and with the Ki index, slightly higher than 2.2.

\section{Profile 2 - Volcanic Breccia}

In table 3 , it is observed that the area of the reflections around $1.4 \mathrm{~nm}$ decreases from the base to the top of the profile, indicating their alteration with the advance of the weathering towards the surface (data not shown). Concomitantly, there was a relative increase in micas (or illites) in the same direction, without significantly altering the kaolinite contents.

Kaolinite and micas (or illites) are the predominant minerals in most horizons, except for $\mathrm{Cr}$, in which kaolinites are found in proportions similar to minerals with peaks at 1.4 $\mathrm{nm}$ (Table 3).

In all horizons, kaolinite reflections are narrow and acute at the top. However, they present asymmetry (and greater width) in the median and inferior portions, suggesting the presence of interstratified 2:1 layer kaolinite-clay minerals in association with pure kaolinites (Figure 2C and 2D). The disappearance of kaolinite reflections when the samples were heated to $550{ }^{\circ} \mathrm{C}$ confirmed their identification (Dixon, 1989; Testoni et al., 2017; Almeida et al., 2019).

Intense reflections identified mica and/or illites at 1.003, 0.499 , and $0.333 \mathrm{~nm}$, with greater intensity in the A2 (data not shown) and BAi horizons, in the samples saturated with $\mathrm{Mg}$ at $25^{\circ} \mathrm{C}$ (Figure $2 \mathrm{C}$ ). In the heating treatments, a better expression of the $0.999 \mathrm{~nm}$ reflections was observed due to the contraction of the layers of the expandable minerals. Clay minerals with peaks around $1.4 \mathrm{~nm}$ decreased towards the surface, not suffering a substantial change in the position of their reflections in samples with ethylene glycol. However, they suffered partial contraction to values around $1.25 \mathrm{~nm}$ in treatments with $\mathrm{K}$ at $350{ }^{\circ} \mathrm{C}$, revealing that it is an expandable mineral, identified as vermiculite with interlayer hydroxyAl polymers (VHE) (Barnhisel \& Bertsch, 1989; Testoni et al., 2017; Almeida et al., 2019).

\section{Profile 3 - Kimberlite Breccia}

Profile 3, developed from the kimberlite breccia and classified as a Chernossolo Háplico Órtico típico (Hapludolls), showed a dominance of 2:1 clay minerals in all horizons, followed by kaolinites and micas, as indicated by the relative areas of the various minerals in table 3.

In Table 3 and Figure $2 \mathrm{~F}$, it is observed that in the $\mathrm{Cr}$ horizon, practically only a mineral with a reflection around $1.55 \mathrm{~nm}$ was detected; in the sample saturated with $\mathrm{Mg}$ at 25 ${ }^{\circ} \mathrm{C}$, their amounts are reduced by more than half at the most superficial horizon. On the other hand, from the bottom to the top, the proportions of minerals with reflections increase around $1.0 \mathrm{~nm}$ (micas) and $0.72 \mathrm{~nm}$ (kaolinites). Such behavior seems to indicate that minerals with peaks of $1.55 \mathrm{~nm}$ were largely altered by weathering in the more superficial horizons, forming kaolinites, as well as allowing the expression of the mica peaks, more resistant to weathering, by a relative increase in their quantities.

After being solvated with ETG, the 2:1 layers underwent a slight expansion, either forming reflections at $2 \theta$ lower angles, as in $\mathrm{Cr}$ and $\mathrm{C} 1$, or forming a plateau in the other horizons, they all indicated the presence of an expandable mineral. Considering that, in this soil, the presence of phlogopite macrocrystals was identified in expressive proportions in the coarser fractions, this suggests the hypothesis of the presence of vermiculites in the clay fraction since these, in most cases, are formed from the alteration of micas (Douglas, 1989). For the formation of vermiculite, $\mathrm{Mg}$ comes from the weathering of minerals from the olivine and pyroxene groups present in the matrix rock. Although most vermiculites in soils do not expand in solvation treatments, Douglas (1989) refers to the occurrence of low-charge trioctahedral micas, which after saturated with $\mathrm{Mg}$ and treated with ETG, may undergo slight expansion to spacings around 1.55 to $1.6 \mathrm{~nm}$, which occurred in the samples studied, mainly in the last two horizons. Ferreira (2013) found a similar mineralogical composition in Chernosol derived from olivine melilithite from the Lages Plateau.

In the heating treatments of samples saturated with potassium (Figure $2 \mathrm{E}$ and $2 \mathrm{~F}$ ), it is observed that there was a gradual collapse of the layers in all horizons, with a spacing reduction to positions around 1.25 or $1.0 \mathrm{~nm}$. This situation confirms the presence of vermiculites with or without interlayer hydroxy polymers (Douglas, 1989; Almeida et al., 2019). Reflections around $1.0,0.49$, and $0.33 \mathrm{~nm}$ confirm the presence of micas, and/or illites, better visualized only in the first two horizons.

Kaolinite, which occurs in a smaller proportion, increases from the base to the top of the profile (Figure 2E and $2 \mathrm{~F}$ ) and is already detected in low quantities in the $\mathrm{C} 1$ horizon. In addition, quartz (narrow and acute reflection around $0.334 \mathrm{~nm}$ at the two most superficial horizons) and goethite (reflection around $0.415 \mathrm{~nm}$ ) were also identified in this profile.

The presence of high amounts of vermiculites in the closest horizons of the rock, as well as their still expressive presence in the more superficial ones, are therefore compatible with the relatively high activity values of the clay fraction in this 
soil (Table 2), as well as with the Ki index, which was above 3.0 in most horizons. On the other hand, the mentions of trioctahedral vermiculites in Brazilian soils are rare. In acidic soils, under intense weathering, mica is directly transformed to VHE without going through the transformation step into vermiculite (Kampf \& Curi, 2012).

\section{Profile 4 - Phonolitic Tephrite}

Profile 4, formed from the Phonolitic Tephrite rock and classified as Nitossolo Bruno Distrófico húmico (Kandiudox), has similar mineralogy in all analyzed horizons. Kaolinite was the dominant clay mineral, except for Bt1, where there was a predominance of clay minerals with spacing around 1.4 nm (Figure 2G, Table 3). Micas (or illites) were also identified in all horizons in small quantities (Table 3). In even smaller quantities, other minerals present were gibbsite (reflection at $0.48 \mathrm{~nm}$ ) and goethite (reflection at $0.415 \mathrm{~nm}$ ).

Minerals with reflections around $1.4 \mathrm{~nm}$ show a very similar pattern along the horizons (Figure $2 \mathrm{G}$ and $2 \mathrm{H}$ ), despite the semiquantitative differences estimated by the ratio of areas of the main reflections (Table 3 ). The main reflections present asymmetries towards the greater angles (between 1.4 and $1.0 \mathrm{~nm}$ ), clearly indicating the occurrence of expansive 2:1 mica-clay mineral type interstratified in association with the last mentioned ones. There was no substantial change in the position of the $1.4 \mathrm{~nm}$ reflections with ETG treatment. In addition, there was a partial contraction of the layers when the potassium samples were heated to $350{ }^{\circ} \mathrm{C}$, whose peaks were between 1.23 and $1.28 \mathrm{~nm}$. Therefore, they were interpreted as indicative of the presence of VHE in association with interstratified Mica-VHE (Barnhisel \& Bertsch, 1989; Almeida et al., 2019).

The micas (or illites), in low proportions in the samples, were identified by reflections around $1.0,0.5$, and $0.33 \mathrm{~nm}$, whose quantities, estimated by the area ratio of clay minerals, increase from the base to the top of the profile (Table 3).

Kaolinites have broad reflections at $0.710,0.355 \mathrm{~nm}$, and $0.237 \mathrm{~nm}$. They have a slight asymmetry at their base, indicative of the small size of the crystals of this mineral, with the probable structural disorder (Aparicio \& Galán, 1999). Its identification is confirmed by the disappearance of the three reflections mentioned in the heating treatment of samples with potassium at $550{ }^{\circ} \mathrm{C}$ (Figure 2G) (Dixon, 1989; Testoni et al., 2017; Almeida et al., 2019).

The fourth mineral present is gibbsite, represented by low-intensity reflections in samples saturated with $\mathrm{Mg}$, around $0.48 \mathrm{~nm}$, and confirmed by their disappearance when subjected to heating at $350{ }^{\circ} \mathrm{C}$ in potassium treatments (Hsu, 1989). Current environmental conditions do not favor the formation of this mineral due to the anti-gibbsitic effect provided by the presence of high organic matter contents and the intercalation of amorphous polymers in the interlayers of the 2:1 clay minerals. Therefore, its presence in this soil may be related to local microsites in the rock, where the silica leaching processes may have been more intense (Kampf \& Curi, 2012).
Peaks with values at $0.415 \mathrm{~nm}$ indicate the presence of goethite, an oxyhydroxide responsible for the predominantly brown colors of the soil.

\section{Profile 5 - Phonolite}

In profile 5, which originated from the phonolite and classified as a Cambissolo Húmico Alumínico típico (Humudepts), the mineralogy was similar in all horizons, composed mainly of kaolinite and clay minerals of 2:1 layer, with peaks around $1.4 \mathrm{~nm}$ and less expressive amounts of micas and/or illites.

From the base to the top of the profile, an increase in clay minerals with reflections of $1.4 \mathrm{~nm}$ is observed (Table 3 ). In samples with $\mathrm{Mg}$, there is a slight asymmetry towards the greater angles, suggesting the presence of expandable 2:1 layer mica-clay mineral interstratified. There was no change in the position of the reflections due to glycolation, but particularly in the $\mathrm{C} 2$ horizon, heating the samples with $\mathrm{K}$ to $350^{\circ} \mathrm{C}$ causes the layers to contract almost completely, a behavior similar to that of vermiculites, with low intercalation of hydroxy-Al polymers between layers. In the $\mathrm{A} 2$ and $\mathrm{Bi}$ horizons, there is also no expansion of the layers with the ETG treatment. However, heating to $350{ }^{\circ} \mathrm{C}$ does not cause a complete collapse of the layers, maintaining a small reflection in the spacing around 1.1 to $1.3 \mathrm{~nm}$, thus revealing that it is VHE. This behavior indicates that, closer to the rock, the conditions were favorable to the formation of purer vermiculites. At the same time, in the more superficial horizons, due to the intensification of the weathering and leaching processes of the bases, the greater amount of Al favors its intercalation in the interlayer spaces, forming more VHE.

Kaolinite, present in all horizons in relatively similar proportions (intense reflections at $0.712,0.356$, and 0.237 $\mathrm{nm}$ ) (Figure 2I), is confirmed by the disappearance of these reflections in heating treatments at $550{ }^{\circ} \mathrm{C}$.

The amounts of micas or illites decrease from the base to the top of the profile (Table 3), probably due to their gradual transformation into VHE or their destruction by weathering, forming kaolinites. There is also gibbsite in small quantities, with reflections at $0.483 \mathrm{~nm}$ and quartz, with reflections at 0.424 and 0.333 .

Relationship between mineralogy, chemical properties, and soil genesis

In practically all profiles, the marked influence of the chemical and mineralogical composition of the matrix rock in the genesis of the soils was evidenced, where those with higher contents of $\mathrm{CaO}$ and $\mathrm{MgO}$, and lower contents of $\mathrm{SiO} 2$ (Kimberlite Breccia and Phonolithic Tephrite), tended to form soils with higher $\mathrm{pH}$ values, higher base content, and lower exchangeable aluminum contents.

Goethite was the only iron oxyhydroxide detected in soils, being responsible for their brownish colors. The wet and cold environment of the Lages Plateau, associated with high levels of organic matter (Almeida et al., 2019), the longer average residence time of water in the soil, causing slower oxidation 
of iron, favored the formation of goethite, as widely reported in similar environments (Schwertmann, 1985).

In profiles P1 and P5 developed respectively from nepheline syenite and phonolite, the mineral constituents of these rocks, rich in feldspar and feldspathoid and poor in mafic minerals, suffered intense weathering in the wet and cold environment of the Lages Plateau, leading to the formation of Humudepts (Cambissolo Háplico ou Húmico), with acidic reaction, with low sum and base saturation and with high levels of exchangeable aluminum, even being soils with incipient development. Besides the dominance of kaolinite, there is expressive participation of VHE and interstratified. Despite having CEC and lower expansivity than their pure counterparts (Barnhisel \& Bertsch, 1989), such clay minerals certainly contributed to the increase in negative charges, whose clay activity was greater than 20 $\mathrm{cmol}_{\mathrm{c}} \mathrm{kg}^{-1}$ in both cases.

The rock of the P2 profile (kimberlite breccia) presented low calcium and magnesium oxides content, standing out. However, for the high $\mathrm{K}_{2} \mathrm{O}$ contents, surpassing $8 \%$, the highest content among the studied rocks (Table 1). The chemical poverty in calcium and magnesium of this rock is the main cause of the very low content of these exchangeable cations in the Humudepts (Cambissolo Háplico) developed from it. The mineralogy of the clay fraction was similar to that of the nepheline syenite profile, composed of kaolinite with expressive proportions of VHE and illites, responsible for clay activity values also above $20 \mathrm{cmol}_{c} \mathrm{~kg}^{-1}$, a situation compatible with the Ki values, around 2.4. The soil appears to have been developed from the weathering alteration of the "in situ" substrate.

As for the P3 profile, the chemical composition of the rock revealed the highest content of $\mathrm{Ca}$ and $\mathrm{Mg}$ oxides among the studied rocks, as well as $\mathrm{TiO}_{2}$, and the lowest content of $\mathrm{Al}_{2} \mathrm{O}_{3}$ (Table 1). The Hapludolls (Chernossolo Háplico) developed from this rock, resulting from the alteration of the in-situ rock, of eutroferric character, was the only soil that presented high natural fertility among the studied ones, with high contents of exchangeable $\mathrm{Ca}$ and $\mathrm{Mg}$, absence of exchangeable $\mathrm{Al}$, the activity of clay fraction greater than $33 \mathrm{cmol}_{c} \mathrm{~kg}^{-1}$ and Ki values greater than 3.0. Furthermore, low-charge trioctahedral vermiculites were practically the only clay minerals present in the $\mathrm{Cr}$ horizon, which are still largely preserved in association with kaolinites in the more superficial horizons. These characteristics point to a very recent origin of this soil, whose rock richness in more easily weatherable primary minerals, such as olivines, pyroxenes, and phlogopites, contributed to preserving a soil with high natural fertility, despite the humid environment currently dominant in the Lages Plateau. Soil similar to the one studied was identified in a restricted area in Palmeira (SC), by Ferreira (2013), developed from the ultrabasic rock olivine melilithite.

The P4 profile Kandiudox (Nitossolo Bruno), developed from phonolitic tephrite, in pediment position, unlike the other soils developed on alkaline rocks (P1 and P5), which presented very low sum and base saturation and aluminum character, presented higher values for the two first attributes, notably in the more superficial horizons. Smaller amounts of exchangeable aluminum, pointing to a slight improvement in natural fertility. It showed similarities in the mineralogical composition with the soils corresponding to profiles P1, P2, and P5 (Kaolinites and VHE), but with the addition of MicaVHE interstratified.

\section{Conclusions}

Profiles P1, P2, and P5 had similar chemical, physical, and mineralogical characteristics. They are clayey, acidic soils with kaolinite associated with vermiculite with hydroxy-Al interlayers (VHE) and smaller amounts of mica and/or illite.

The soil of the P4 profile, developed from the phonolitic tephrite, showed a significant improvement in chemical properties compared to that seen in the P1, P2, and P5 profiles. The mineralogical composition of this soil indicated kaolinite as the predominant mineral, VHE, and mica-VHE interstratified, with small amounts of gibbsite.

The P3 profile, unlike the others, showed chemical properties indicating more fertile soil. In addition, the mineralogical composition of this profile showed a predominance of trioctahedral vermiculites in the clay fraction.

Soils P1 and P2 were classified as typical Cambissolo Háplico Alumínico típico, P3 as Chernossolo Háplico Órtico típico, P4 as Nitossolo Bruno Distrófico húmico, and P5 as Cambissolo Húmico Aluminico típico.

\section{Compliance with Ethical Standards}

Author contributions: Conceptualization: AEDVL, JAA; Data curation: AEDVL, JAA; Formal analysis: AEDVL, JAA; Funding acquisition: JAA; Investigation: AEDVL, JAA; Methodology: AEDVL, JAA; Project administration: JAA; Resources: AEDVL, JAA; GOMC; CJRL; Software: AEDVL; Supervision: JAA; Validation: AEDVL, JAA; GOMC; CJRL; Visualization: GOMC; CJRL; Writing - original draft: AEDVL, GOMC; CJRL; Writing review \& editing: AEDVL, GOMC; CJRL.

Conflict of interest: The authors declared that there are no conflicts of interest (professional or financial) that could influence the article.

Funding: Coordenação de Aperfeiçoamento de Pessoal de Nível Superior - Brasil (CAPES) - Finance Code 001.

\section{Literature Cited}

Almeida, J. A.; Corrêa, J.; Schmitt, C. Clay mineralogy of Basaltic Hillsides soils in the western state of Santa Catarina. Revista Brasileira de Ciência do Solo, v42, e0170086, 2018. https://doi. org/10.1590/18069657rbcs20170086.

Almeida, J. A.; Silva, T. P.; Cunha, G. O. M.; Spido, D. R.; Silva, F. T. $\mathrm{S}$. Atributos químicos, físicos e mineralógicos de solos derivados de rochas sedimentares do Planalto de Lages-SC, Brasil. Revista Brasileira de Ciências Agrárias, v.14, n.3, e6576, 2019. https:// doi.org/10.5039/agraria.v14i3a6576. 
Aparicio, P.; Galán, E. Mineralogical interference on Kaolinite crystallinity index measurements. Clays and Clays Minerals, v.47, n.1, p.12-27, 1999. https://doi.org/10.1346/ CCMN.1999.0470102.

Aumond, J. J.; Scheibe, L. F. O fonolito de Lages - Santa Catarina, um novo fundente cerâmico brasileiro. Cerâmica Industrial, v.1, n.2, p.17-21, 1996. https://www.ceramicaindustrial.org.br/journal/ ci/article/587656f87f8c9d6e028b45d1. 06 Sep. 2020.

Barnhisel, R. I.; Bertsch, P. M. Chlorites and hydroxy-interlayered vermiculite and smectite. In: Dixon, J.B.; Weed, S.B. (Eds.). Minerals in soil environments. 2.ed. Madison: SSSA, 1989. v.1, chap. 15, p.729-787. https://doi.org/10.2136/sssabookser1.2ed. c15.

Bortoluzzi, E. C; Pernes. M; Tessier, D. Interestratificado caulinitaesmectita em um Argilossolo desenvolvido a partir de rocha sedimentar do Sul do Brasil. Revista Brasileira de Ciência do Solo, v.31, n.6, p.1291-1300, 2007. https://doi.org/10.1590/S010006832007000600008.

Brindley, G.W.; Brown, G. (Eds.). Cristal structures of clay minerals and their $X$ ray identification. London: Mineralogical Society, 1980. 495p. (Mineralogical Society Monograph, 5). https://doi. org/10.1180/mono-5.

Comin-Chiaramonti, P.; Ruberti, E.; Gomes, C.; Antonini, P. Mato Preto alcaline-carbonatite complex: geochimestry and isotope (O-C, Sr-Nd) constraints. Geochimica Brasiliensis, v.15, n.1/2, p.23-34, 2001. https://doi.org/10.21715/gb.v15i1.181.

Costa, V. S.; Figueiredo, B.R.; Weska, R.K. Estudos mineralógicos e químicos do kimberlito Botovi 6 (MT) em comparação com as intrusões Três Ranchos 4, GO e Limeira 1, MG. Geochimica Brasiliensis, v.11, n.1, p.53-71, 1997. https://doi.org/10.21715/ gb.v11i1.118.

Dixon, J.B. Kaolin and serpentine group mineral. In: Dixon, J.B.; Weed, S.B. (Eds.). Minerals in soil environments. 2.ed. Madison: SSSA, 1989. v.1, chap. 10, p.467-526. https://doi.org/10.2136/ sssabookser1.2ed.c10.

Douglas, L. A. Vermiculites. In: Dixon, J.B.; Weed, S. B. (Eds.). Minerals in soil environments. Madison: SSSA, 1989. v.1, chap. 13, p.635674. https://doi.org/10.2136/sssabookser1.2ed.c13.

Empresa Brasileira de Pesquisa Agropecuária - Embrapa. Manual de métodos de análise de solo. 3.ed. Rio de Janeiro: Embrapa Solos, 2017. 573p.'

Empresa Brasileira de Pesquisa Agropecuária - Embrapa. Manual de métodos de análise de solo. Rio de Janeiro: Embrapa, 1979. 247p.

Ferreira, E. R. N. C. Química e mineralogia de solos desenvolvidos de rochas alcalinas e ultrabásicas do domo de Lages, SC. Lages: Universidade do Estado de

Hsu, P. H. Aluminum oxides and oxyhydroxides. In: Dixon, J.B.; Weed, S.B. (Eds.). Minerals in soil environments. 2.ed. Madison: SSSA, 1989. v.1, chap. 7, p.331-376. https://doi.org/10.2136/ sssabookser1.2ed.c7.

Jackson, M. L. Soil chemical analysis: advanced course. 2. ed. Madison: Department of Soil Science; University of Wisconsin, 1965. 895p.

Jiang, J.; Wang, Y. P.; Yu, M.; Cao, N.; Yan, J. Soil organic matter is important for acid buffering and reducing aluminum leaching from acidic forest soils. Chemical Geology, v.501, p.86-94, 2018. https://doi.org/10.1016/j.chemgeo.2018.10.009.
Kämpf, N.; Curi, N. Formação e evolução do solo (pedogênese). In: Ker, J. C.; Curi, N.; Schaefer, C. E. G. R.; Vidal-Torrado, P. (Eds.). Pedologia fundamentos. Viçosa: SBCS, 2012. Chap. 13, p.208-248p.

Karathanasis, A. D.; Adams, F.; Hajek, B. F. Stability relationships in kaolinita, gibbsite anda Al-hydroxy interlayered vermiculite soil systems. Soil Science Society of American Journal, v.47, n.6, p.1247-1251, 1983. https://doi.org/10.2136/ sssaj1983.03615995004700060036x.

Le Maitre, R. W. Igneous rocks: a classification and glossary of terms. Recommendations of the International Union of Geological Sciences, Subcommission of the Systematics of Igneous Rocks. 2.ed. Cambridge: Cambridge University Press, 2002. 252p. https:// doi.org/10.1017/СBO9780511535581.

Leinz, V.; Amaral, S. E. do. Geologia geral. São Paulo: Nacional, 1985. $397 p$.

Lu, X.; Mao, Q.; Mo, J.; Gilliam, F. S.; Zhou, G.; Luo, Y.; Zhang, W.; Huang, J. Divergent responses of soil buffering capacity to long-term $\mathrm{N}$ deposition in three typical tropical forests with different land-use history. Environmental Science Technology, v.9, n.7, p.4072-4080, 2015. https://doi.org/10.1021/es5047233.

Machado, R.; Roldan, L. F.; Jacques, P. D. et al Tectônica transcorrente Mesozoica-Cenozoica no Domo de Lages - Santa Catarina. Revista Brasileira de Geociências, v.42, n.4, p.799-811, 2012. https://doi. org/10.5327/Z0375-75362012000400011.

Martins, V.; Guelfi Silva, D. R.; Marchi, G.; Leite, M. C. A.; Martins, E. S.; Gonçalves, A. S. F.; E Guilherme, L. R. G. Effect of alternative multinutrient sources on soil chemical properties. Revista Brasileira de Ciência do Solo, v. 39, n. 1, p. 194-204, 2015. https://doi.org/10. 1590/01000683rbcs20150587.

Motoki, A.; Araújo, A. L.; Sichel, S. E.; Motoki, K. F.; Silva, S. M. Nepheline syenite magma differentiation process by continental crustal assimilation for the Cabo Frio Island intrusive complex, State of Rio de Janeiro, Brazil. Geociências, v. 32, n.2, p. 195-218, 2013. http://www.periodicos.rc.biblioteca.unesp.br/index.php/ geociencias/article/download/8329/5886. 02 Aug. 2020

Ribeiro, G. M. Caracterização de pós de rochas silicáticas, avaliação da solubilidade em ácidos orgânicos e potencial de liberação de nutrientes como remineralizadores de solos agrícolas. Lages: Universidade do Estado de Santa Catarina, 2018. 107p. Tese Doutorado. https://www.udesc.br/arquivos/cav/id_ cpmenu/1478/TESE_GENICELLI_15694159594665_1478.pdf. 25 Aug. 2020.

Roldan, L.; Machado, R.; Steiner, S. dos S.; Warren, L.V. Análise de lineamentos estruturais no Domo de Lages (SC) com uso de imagens de satélite e mapas de relevo sombreado. Geologia USP. Série Cientifica, v.10, n.2, p.57-72, 2010. https://doi.org/10.5327/ Z1519-874X2010000200005.

Santa Catarina. 2013. 161p. Tese Doutorado. http://www.uniedu.sed. sc.gov.br/wp-content/uploads/2014/12/Tese-\%C3\%89len-RamosNichele-Campos-Ferreira.pdf. 06 Sep. 2020.

Santa Catarina. Secretaria do Estado do Planejamento. Diretoria de Estatístca e Cartografia. Atlas Geográfico de Santa Catarina: Diversidade da natureza: Fascículo 2. Florianópolis: Ed. da UDESC, 2015. 188p. Santos, H. G.; Jacomine, P. K. T.; Anjos, L. H. C. dos; Oliveira, V. A.; Lumbreras, J. F.; Coelho, M. R.; Almeida, J. A.; Araujo Filho, J. C.; Oliveira, J. B.; Cunha, T. J. F. Sistema brasileiro de classificação de solos. Brasília: Embrapa, 2018. 355p. 
Santos, R. D.; Santos H. G.; Ker, J. C.; Anjos, L. H. C.; Shimizu, S. H. Manual de descrição e coleta do solo no campo. 7.ed. Viçosa: SBCS; CNPS, 2015. 102p.

Scheibe, L. F. Geologia e petrologia do distrito alcalino de Lages, SC. São Paulo: Universidade de São Paulo; Instituto de Geociências, 1986. 224p. Tese Doutorado. https://doi.org/10.11606/T.44.2016.tde16022016-131224.

Schwertmann, U. Occurrence and formation of iron oxides in various pedoenvinriments. In: Stucki, J. W.; Goodman, B.A.; Schwertmann, U. (Eds.). Iron in soils an clay minerals. Dordrecht: D Reidel, 1988. Chap. 11, p. 267-308. https://doi.org/10.1007/978-94-009-4007-9_11.

Serviço Geológico do Brasil - CPRM. Mapa geológico do estado de Santa Catarina. Porto Alegre, 2014. https://rigeo.cprm.gov.br/ xmlui/handle/doc/17996?show=full. 08 May. 2020.

Silva, M. B. E; Lumbreras, J. F.; Coelho, M. R.; Oliveira, V. A. de (Eds.). Guia de campo da XIII Reunião Brasileira de Classificação e Correlação de Solos: RCC do Maranhão. Brasília: Embrapa, 2020. E-book. https:// ainfo.cnptia.embrapa.br/digital/bitstream/item/218466/1/Guiade-campo-da-XIII-RCC-Maranhao.epub. 25 Aug. 2020.
Soil Survey Staff. Keys to soil taxonomy. 12.ed. Washington USDA; Natural Resources Conservation Service, 2014. 362p. https://www.nrcs.usda.gov/wps/PA_NRCSConsumption/ download?cid=stelprdb1252094\&ext=pdf. 19 Aug. 2020.

Teske, R.; Almeida, J. A.; Hoffer, A.; Neto, A. L. Caracterização mineralógica dos solos derivados de rochas efusivas no Planalto Sul de Santa Catarina. Revista de Ciências Agroveterinárias, v.12, n.2, p.187-198, 2013. https:// www.revistas.udesc.br/index.php/agroveterinaria/article/ view/5213. 28 Jul. 2020.

Testoni, S. A.; Almeida, J. A.; Da Silva, L.; Andrade, G. R. P. Clay mineralogy of Brazilian Oxisols with shrinkage properties. Revista Brasileira de Ciência do Solo, v.41, e0160487, 2017. https://doi.org/10.1590/18069657rbcs20160487.

Whittig, L. D.; Allardice, W. R. X-ray diffraction techniches. In: Klute, A. (Ed.). Methods of soil analysis: part 1 - physical and mineralogical methods, 5.1. 2.ed. Madison: SSSA, 1986. Chap. 12, p. 331-362. https://doi.org/10.2136/ sssabookser5.1.2ed.c12. 